UDC 616.367-007.272-092.9-091.8:616.36-008.64
DOI: $10.15587 / 2519-4798.2020 .193845$

\title{
MORPHOMETRIC PARAMETERS OF HEPATOCYTES IN EXPERIMENTAL COMPLETE EXTRAHEPATIC BILE DUCT OBSTRUCTION
}

\author{
I. Mamontov, I. Ivakhno, T. Tamm, V. Panasenko, V. Padalko, I. Zulfugarov
}

Зміни печінки при повній обструкиії позапечінкових жовчних шляхів (ПОПЖШ) з урахуванням морфометричних показників можуть відображати наступаючу декомпенсацію функиії печінки $і$ служити об 'єктивними критеріями прогнозу перебігу захворювання.

Мета: вивчення морфологічних змін гепатоцитів при експериментальній ПОПЖШ з використанням макро- та мікроморфометріi.

Матеріали та методи. На 41 щурах ПОПЖШ відтворювали шляхом перев'язки $і$ перетину загальної жовчної протоки. Тварин виводили з експерименту на 1, 3, 7, 14, 21, 28 і 35 добу. Контроль - 10 неоперованих щурів. Досліджували вміст загального білірубіну крові (ЗБК), об 'єм печінки (ОП), площза гепаточитів (ПГ), ядерно ичитоплазматичне відношення (ЯЦВ) гепатоцчитів, об'ємна щүільність гепатоиитів (ОЩГ). За допомогою ОП і ОЩГ вираховували загальний об 'єм гепатоичитів (ЗОГ).

Результати. Найбільша летальність припадає на 22-35 добу експерименту (7 з 11 тварин), в ході якого

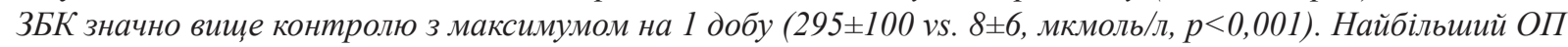

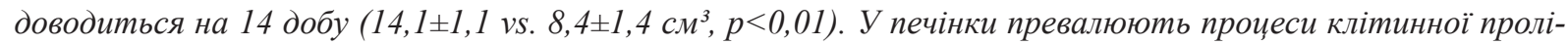
ферації, фиброзування, з поступовим витісненням гепатоцитів проліферуючими жовчними протоками $i$ повною втратою нормальної гістоструктури. Частка гепатоцитів в печінці (ОЩГ) прогресивно знижу-

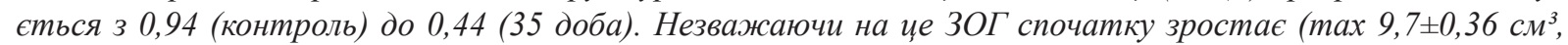

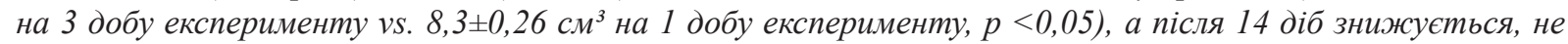

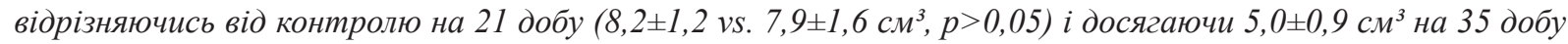
експерименту ( $<<0,05$ в порівнянні з тах на 3 добу). Статистично значущих відмінностей ПГ в ході експерименту не виявлено, а ЯЦВ, щзо відображає проліферативну активність гепатоцитів, має свій максимум

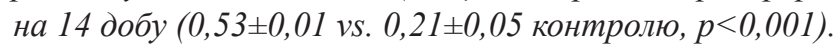

Висновок: при експериментальній ПОПЖШ зниження ОЩГ менше 60 \% $і$ зниження ЗОГ менш значення характерного для нормальної печінки супроводжується піком летальності, тобто є ознакою декомпенсаиії печінкової функиії. Цьому передує максимальна проліферативна активність гепатоцитів, критерієм якої є показник ЯЦВ

Ключові слова: експериментальна обструкиія жовчних шляхів, холестаз, гепатоцит, морфологія печінки, морфометрія

Copyright (C) 2020, I. Mamontov, I. Ivakhno, T. Tamm, V. Panasenko, V. Padalko, I. Zulfugarov.

This is an open access article under the CC BY license (http://creativecommons.org/licenses/by/4.0).

\section{Introduction}

Obstruction of the extrahepatic bile ducts is a frequent complication of both tumor and non-tumor diseases of the extrahepatic biliary tract and nearby organs [1]. Prolonged obstruction ultimately leads to biliary hyperplasia, fibrosis, liver cirrhosis and liver failure [2, 3].

Experimental study of obstructive cholestasis makes it possible to investigate liver pathomorphogenesis, reparation peculiarities, cellular reaction and development of fibrosis, cirrhosis of the liver, nature and course of cholestasis complications, and much more [4, 5].

Ligation of the bile duct with its subsequent transection is the most common experimental model for complete and prolonged obstruction of extrahepatic biliary tract [5].

Pathological changes in the liver during experimental complete extrahepatic bile duct obstruction (CEBDO) have been comprehensively studied [2, 3].

However, the objective morphometric parameters of the liver, and especially of hepatocytes, allowing eval- uating decompensation of the hepatic function and determining prognosis of the pathological condition, have not been studied sufficiently $[6,7]$.

Therefore, the aim of this research is to evaluate morphological changes of hepatocytes in experimental complete obstruction of extrahepatic bile duct using macro- and micromorphometry.

\section{Materials and methods}

Male Albino Wistar rats with body weights of 270-310 g kept under standard laboratory conditions were used in the experiment that was carried out in the Institute of Biology of the Karazin Kharkiv National University and approved by bioethics committee.

Cholestasis was studied on the model of complete obstruction of extrahepatic bile duct $[5,7]$. The operation was performed under antiseptic conditions, with general anesthesia. On 41 animals after middle laparotomy, proximally to pancreatic ducts the common bile duct was dissected, ligated and transected between the two 
ligatures (silk 5/0). Ten non-operated rats were used as a control group.

The checkpoints were on postoperative Day 1, 3, 7, 14, 21, 28, and 35. Blood and liver samples were collected. The volume of the liver ( $\mathrm{LV}, \mathrm{cm} 3)$ was determined by the volume of water displaced after its immersion into a laboratory flask with a graduated scale of volume.

The serum from collected blood was analyzed to determine total bilirubin level with manual colorimetric method by Jendrassik [8].

Liver samples - 3-4 $\mu \mathrm{m}$ paraffin-embedded sections were stained using hematoxylin and eosin and by the Van Gieson's method. Images of microscopic slides were captured using Primo Star (Carl Zeiss) microscope equipped with a digital camera (AxioCam ERc5s). Morphometric analysis was performed [9]. Images were further analysed using ImageJ software.

The following micromorphometric parameters were studied: the area of hepatocytes $\left(\mathrm{AH}, \mu \mathrm{m}^{2}\right)$; the nucleus area of hepatocytes $\left(\mathrm{NAH}, \mu \mathrm{m}^{2}\right)$; hepatocyte nuclear-cytoplasmic ratio $\left(\mathrm{HNCR}, \mu \mathrm{m}^{2} / \mu \mathrm{m}^{2}\right.$ ), which is a ratio between the area of their nuclei and the area of their cytoplasm; hepatocyte bulk density ( $\left.\mathrm{HBD}, \mathrm{cm}^{3} / \mathrm{cm}^{3}\right)$, which is a ratio between the volume of the hepatocytes and the volume of the entire liver tissue (can be expressed as a percentage (HBD, \%) [9]. In addition, the in-house parameter based on micro- and macromorphometry data, i. e. the total volume of hepatocytes $\left(\mathrm{TVH}, \mathrm{cm}^{3}\right)$, was calculated by the following formula: HBD $\times \mathrm{LV}$.

The livers of the dead animals were not submitted to analysis.

Statistical analysis. All values are expressed as means \pm standard deviation. The Student $t$ test was used. For categorical data the $\chi^{2}$-test was used. $\mathrm{P}<0.05$ was considered significant.

\section{Results}

The results of a morphometric study of the liver, as well as the levels of total blood bilirubin in the control and experimental groups are presented in Table 1.

In the control group, the mean value of total blood bilirubin was $8 \pm 6 \mu \mathrm{mol} / \mathrm{l}$, and $\mathrm{LV}$ was $8.4 \pm 1.4 \mathrm{~cm}^{3}$.

Histological examination of the livers in the control group, where there was no pathology, revealed normal histological liver structure with lobular zonality, the presence of clear cords consisting of monomorphic mononuclear hepatocytes with clearly visible sinusoids. The nucleus area of hepatocytes was $30.8 \pm 7.9 \mu \mathrm{m}^{2}$, the area of cytoplasm was $150.3 \pm 45.3 \mu \mathrm{m}^{2}$, the area of hepatocytes was $180 \pm 50.1 \mu \mathrm{m}^{2}$; accordingly, the mean HNCR was $0.208 \pm 0.05 \mu \mathrm{m}^{2} / \mu \mathrm{m}^{2}$.

In the control group, the HBD was $0.94 \pm 0.02 \mathrm{~cm}^{3 /}$ $\mathrm{cm}^{3}$. As a percentage, this means that normally the hepatocyte volume is $94 \%$ of the total volume of the liver. A significantly smaller area was occupied by portal tracts $\left(0.01 \pm 0.005 \mathrm{~cm}^{3} / \mathrm{cm}^{3}\right)$ and sinusoidal spaces with central veins $\left(0.05 \pm 0.01 \mathrm{~cm}^{3} / \mathrm{cm}^{3}\right)$. Taking into account the total liver volume, the TVH was $7.9 \pm 1.6 \mathrm{~cm}^{3}$.

In the experimental group of 41 animals, 11 rats died (26,8 \%): two rats died during Week 1- on Day 2 and Day 3, 2 animals on Week 3, 5 animals on Week 4, and 2 animals on Week 5 of the experiment.

At all the time points of the experiment, the level of total blood bilirubin was significantly higher than in the control group (Table 1), with its maximum observed on Day 1 of the experiment $(295 \pm 100 \mu \mathrm{mol} / \mathrm{l})$.

On Day 1, 3, 7, and 14, there was an increase in LV (Table 1) with the maximum value observed on Day 14 and a significant difference as compared to previous time points on Day 3 and Day 7 ( $<<0.05, p<0.001$, respectively). Subsequently, the liver volume decreased, reaching a value of $11.3 \pm 3.3 \mathrm{~cm}^{3}$ on Day 35 , and demonstrated no significant difference if compared to the control group.

Histological liver changes recorded on Day 1 were characterized by the processes of alteration and acute inflammation, i. e. edema and plethora of blood vessels with their leukocyte infiltration, focal hepatocellular necrosis, and dilation of the bile ducts. There was a decrease in the $\mathrm{HBD}$, an increase in the TVH and HNCR, however these changes were not statistically significant $(p>0.05)$.

Table 1

Total blood bilirubin and morphometric parameters of the liver in

CEBDO at different time points of the experiment

\begin{tabular}{|c|c|c|c|c|c|c|c|c|}
\hline \multirow{2}{*}{ Duration of the experiment } & \multirow{2}{*}{$\begin{array}{c}\text { Control, } \\
\mathrm{n}=10\end{array}$} & \multicolumn{10}{|c|}{ Day } \\
\cline { 3 - 9 } & & $\mathrm{n}=5$ & $\begin{array}{c}3, \\
\mathrm{n}=3\end{array}$ & $\begin{array}{c}7, \\
\mathrm{n}=4\end{array}$ & $\begin{array}{c}14, \\
\mathrm{n}=6\end{array}$ & $\begin{array}{c}21, \\
\mathrm{n}=6\end{array}$ & $\begin{array}{c}28, \\
\mathrm{n}=4\end{array}$ & $\begin{array}{c}35, \\
\mathrm{n}=2\end{array}$ \\
\hline $\mathrm{TB}, \mu \mathrm{mol} / 1$ & $8 \pm 6$ & $295 \pm 100^{*}$ & $247 \pm 20$ & $185 \pm 10$ & $180 \pm 7$ & $122 \pm 16$ & $102 \pm 17$ & $124 \pm 16$ \\
\hline $\mathrm{LV}, \mathrm{cm}^{3}$ & $8.4 \pm 1.4$ & $9.3 \pm 0.3$ & $11.4 \pm 0.2^{*}$ & $10.8 \pm 1.2^{*}$ & $14.1 \pm 1.1$ & $13.7 \pm 1$ & $13.3 \pm 1.7$ & $11.3 \pm 3.3$ \\
\hline $\mathrm{HBD}, \mathrm{cm}^{3} / \mathrm{cm}^{3}$ & $0.94 \pm 0.02$ & $0.89 \pm 0.02$ & $0.85 \pm 0.01$ & $0.83 \pm 0.02$ & $0.67 \pm 0.04 *$ & $0.6 \pm 0.06$ & $0.47 \pm 0.07$ & $0.44 \pm 0.01$ \\
\hline $\mathrm{TVH}, \mathrm{cm}^{3}$ & $7.9 \pm 1.6$ & $8.3 \pm 0.26$ & $9.7 \pm 0.36^{*}$ & $9.0 \pm 0.8$ & $9.5 \pm 1.15$ & $8.2 \pm 1.2$ & $6.3 \pm 0.6 * *$ & $5.0 \pm 0.9 * *$ \\
\hline $\mathrm{AH}, \mu \mathrm{m}^{2}$ & $180 \pm 50$ & $188 \pm 13$ & $177 \pm 8.3$ & $160 \pm 24$ & $164 \pm 9.33$ & $166 \pm 10.1$ & $206 \pm 13.5$ & $199 \pm 28.3$ \\
\hline $\mathrm{HNCR}, \mu \mathrm{m}^{2} / \mu \mathrm{m}^{2}$ & $0.21 \pm 0.05$ & $0.31 \pm 0.02$ & $0.40 \pm 0.02 *$ & $0.45 \pm 0.04$ & $0.53 \pm 0.01$ & $0.43 \pm 0.02 *$ & $0.32 \pm 0.01 *$ & $0.34 \pm 0.001$ \\
\hline
\end{tabular}

Note: * - significant differences $(p<0.05)$ when compared to the previous time point of the experiment; ** - significant differences $(p<0.05)$ when compared to a maximum observed on Day 3 
On Day 3 of CEBTO, the signs of acutely developed pathological process, i. e. edema and plethora of blood vessels with their leukocyte infiltration, were persisting. In all cases, there were focal hepatocellular necrosis. Additionally, proliferation of the bile ducts was observed. A pronounced proliferation of hepatocytes with frequently occurring binuclear cells, mitoses, and an increase in HNCR as compared to Day $1(\mathrm{p}<0.05)$ and to the control group $(\mathrm{p}<0.01)$ was registered. These changes alongside with a slight decrease in the HBD index led to an increase in TVH value of the entire liver as compared to Day 1 of the experiment $(\mathrm{p}<0.05)$.

On Day 7, manifestation of acute inflammation signs (edema, plethora of blood vessels with their leukocyte infiltration) was diminished. The appearance of rare porto-portal septa formed mainly due to the newly formed bile ducts and the connective tissue scaffolds made of thin collagen fibres was recorded. Due to proliferation of the bile ducts and the appearance of fibrosis of the portal areas, the levels of HBD и TVH were slightly reduced (Table 1). The area of hepatocytes and HNCR index continued to decrease as well (Table 1). However, these changes are not statistically significant as compared to Day $3(\mathrm{p}>0.05)$.

On Day 14, upon a significant dilation of the portal zones with the signs of bile duct proliferation, fibrosis and liver histoarchitecture restructuring, there was a displacement of functionally active liver parenchyma and, accordingly, a decrease in the HBD rate to $0.67 \mathrm{~cm}^{3} / \mathrm{cm}^{3}$, which is statistically significant as compared to Day 7 of the experiment $(\mathrm{p}<0.05)$. The TVH index of $9.5 \pm 1.15 \mathrm{~cm}^{3}$ was slightly higher than on Day 7 ( $p>0.05)$, which can be explained by the ongoing proliferation of hepatocytes, and by increased hepatocyte area and by increasing of HNCR index.

On Day 21 of the experiment, the proliferation of cholangiocytes continued to be on a rise, the correct lobular structure of the liver was completely lost, and the remaining parenchyma was represented by islets of false lobes or groups of hepatocytes that had been lost their beamed structure and surrounded by newly formed cholangiocytes of different stage of differentiation - from oval cells to mature ones. Newly formed cholangiocytes and bile ducts were accompanied by slight fibrosis in the form of a delicate net of thin collagen fibres. However, Van Gieson's staining showed a distinct presence of connective tissue fibres only at the sites of preexisting septa and their absence in the areas of liver parenchyma displacement with newly formed cholangiocytes. Due to the pronounced displacement of the liver parenchyma by proliferating cholangiocytes and stroma, with total loss of the correct lobular structure of the liver, the bulk density of hepatocytes continued to decrease up to $0.6 \pm$ $\pm 0.06 \mathrm{~cm}^{3} / \mathrm{cm}^{3}$. The TVH index decreased as compared to Day $14\left(8.2 \pm 1.2 \mathrm{~cm}^{3}\right)$, which was accompanied by a decreasing HNCR index $(\mathrm{p}<0.05)$.

At the end of Day 28, HBD and TVH indices continued to decline due to the progressive displacement of hepatocytes (Table 1). Hepatocytes were mostly located in groups and separately from each other, without formation of lobes.
On the Day 35, the proliferation of cholangiocytes, oval cells, myofibroblasts was extremely pronounced. Upon analysis of the morphometric parameters, we can note the continuing decrease in HBD value with its minimum of $0.44 \pm 0.01 \mathrm{~cm}^{3} / \mathrm{cm}^{3}$. The TVH value also reached its minimum during the experiment $\left(5.0 \pm 0.9 \mathrm{~cm}^{3}\right)$. As compared to Day 28, the HNCR and AH values remained at about the same level (Table 1).

\section{Discussion}

Complete extrahepatic biliary tract obstruction is a serious pathological condition which, if not treated, inevitably leads to death. This has been confirmed by high mortality observed during our experiment, i. e. mortality of $75 \%$ was recorded by Day 35 [7].

In order to investigate liver changes during complete cholestasis, we used the model where the common bile duct is transected between the ligatures $[5,7]$. The transection of the duct is obligatory, because otherwise, if only ligated, the bile flow restores due to compensatory opening and growth of small bile ducts $[5,10]$.

During our experiment, the total bilirubin level reached its maximum on Day 1, with a subsequent gradual decrease. By Day 35, the level of total blood bilirubin was still high $(124 \pm 16 \mu \mathrm{mol} / \mathrm{L})$. Such bilirubin level pattern, with some decreasing during the experiment, does not indicate any restoration of bile flow, but is explained by a reduction of liver blood flow, decreasing bile production by hepatocytes and bile regurgitation into the blood [4].

Considering morphological liver changes, initially (Day 1 and Day 3), because of acutely developed cholestasis, there was a prevailing of inflammatory reaction with edema and focal hepatocellular necrosis. Subsequently, starting on Day 7, there was a predomination of cell proliferation, angiogenesis and fibrosis with gradual displacement of hepatocytes by proliferating bile ducts and, ultimately, complete loss of normal liver histostructure $[2,7]$.

The previous study, with use of the same experimental material, showed morphological changes of liver stromal component [7]. It has been established that in CEBDO, the morphological signs preceding liver decompensation accompanied by a peak level of mortality, are the maximum value of portal zones bulk density and sinusoidal-hepatocyte number, the decrease in HNCR level after its maximum value, which correspondingly reflects a maximum proliferative activity of the bile ducts and activity of sinusoidal cells accompanied by a decrease in proliferative capacity of hepatocytes [7].

In this research, we have been focused on morphometric investigation of hepatocytes.

The maximum LV value exceeding 1.7 times the value in the control group $(\mathrm{p}<0.01)$ was recorded on Day 14 of the experiment (Fig. 1). A certain decrease in LV level on Day 7 of the experiment compared to Day 3 can be explained by a decrease in liver edema that prevailed on Day 1 and Day 3 together with other signs of acute inflammation. In general, an increase in LV is primarily associated with hyperplasia of bile ducts and, to a lesser extent, with hyperplasia of hepatocytes [7]. 
Decrease in the LV after Day 14 can be partially explained by the decreased TVH, which, after the preceding increase, during this stage is progressively goes down (Fig. 1). On Day 28 and Day 35, the differences in the TVH in the experimental group reach the level of statistical significance with the previous maximum $(\mathrm{p}<0.01)$, amounting to values 1.25 and 1.58 times, respectively, less than those in the control group. However, at these time points, the differences from the control group are not significant $(\mathrm{p}>0.05)$.

Despite the increase in TVH index observed up to Day 14, the proportion of hepatocytes in the entire liver decreases during the course of the experiment, what is illustrated by the dynamic pattern of the HBD index (Fig. 2). In the control group, hepatocytes had $94 \%$ of liver volume, then on Day 14 this percentage was $60 \%$, and on Day 35 - only $44 \%$.

The upward TVH trend observed up to Day 14 (Fig. 1) reflects compensatory-adaptive processes and reparative capacity of hepatocytes, which corresponds to the upward HNCR trend (Fig. 2) reflecting proliferative activity of hepatocytes [8]. This period of the experiment is accompanied by low mortality, i. e. only 2 animals died, that confirms effectiveness of these compensatoryadaptive processes.

Subsequently, on Day 21, 28 and 35, there were trends of different nature indicating the breakdown of compensatory-adaptive capacity [7].

The decrease in HNCR level at these time points (Table 1, Fig. 2) is due to a decrease in reparative capacity of the liver cells. The nuclear cytoplasmic ratio on Day 28 and Day $35(0.32 \pm 0.01$ and $0.34 \pm 0.001$, respectively) corresponds to Day 1 cholestasis, which, in case of contemporary extremely pronounced liver changes, represents an evidence of liver decompensation. Reduced proliferative activity of hepatocytes results in decrease in TVH level. At the same time, as mentioned above, on Day 28 and Day 35 TVH level was significantly lower than the maximum that had been reached earlier (Fig. 1).

These morphological signs of compensatory-adaptive exhaustion of hepatocytes are accompanied by a peak mortality (7 animals died between Day 22 and Day 35).

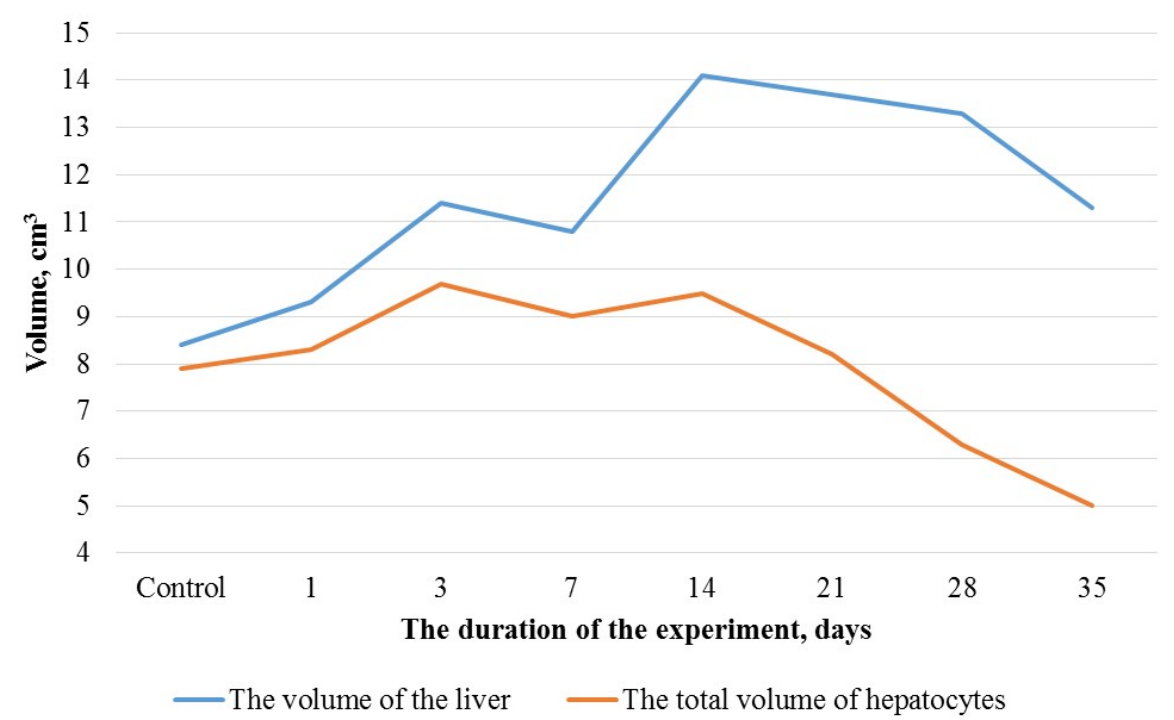

Fig. 1. Volume of liver and total volume of hepatocytes throughout the experiment

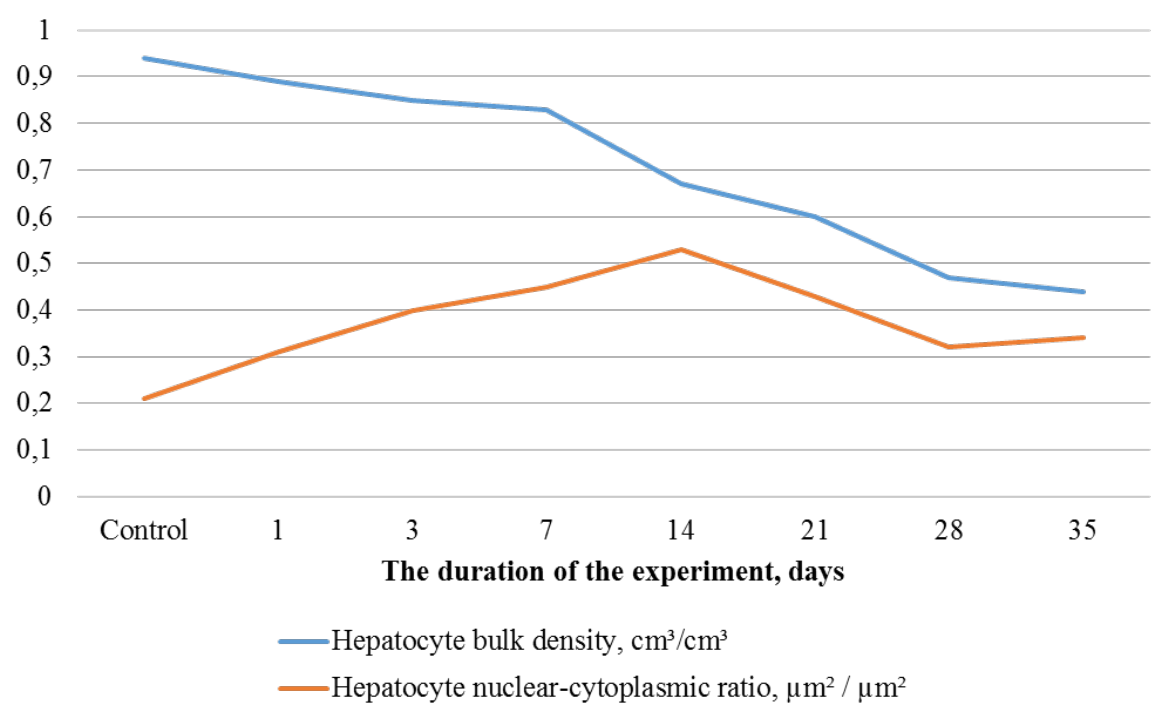

Fig. 2. Hepatocyte bulk density and hepatocyte nuclear-cytoplasmic ratio levels during the experiment 
Therefore, in this study a number of morphometric parameters of hepatocytes in experimental CEBDO have been studied. From the prognostic point of view, the following parameters may draw an attention: $\mathrm{LV}$, HBD, TVH and HNCR. Despite variability of the AH index (Table 1) in the course of the experiment, we have revealed no statistically significant relationship between its value and the CEBDO course.

Liver weight or liver volume may serve as a criterion for the severity of obstructive cholestasis, as well as a prognostic criterion for compensated cirrhosis and fulminant liver failure [11]. In our opinion, the LV index is not able to reflect the severity of liver changes since it depends on many factors, such as newly formed bile ducts, stroma and mesenchymal cells, volume of hepatocytes, liver's plethora, edema, etc.

The HBD index may serve as a criterion for the severity of liver pathology due to its progressive decrease observed throughout the experiment. The HBD value of $0.6 \pm 0.06 \mathrm{~cm}^{3} / \mathrm{cm}^{3}$ was followed by peak mortality on Day 21. In other words, in experimental CEBDO, a decrease in the proportion of hepatocytes by volume of less than $60 \%$ is accompanied by a high mortality. However, this parameter reflects only a proportional characteristic of the volume of all liver hepatocytes.

The TVH determined with consideration of HBD and LV has no such a disadvantage.

The demonstrated pattern of TVH levels allows using this parameter as a criterion for the severity of pathological liver changes, compensatory-adaptive processes, and liver decompensation.

The HNCR parameter is also a conclusive one, which correlates with the TVH dynamics (Table 1), and the peak of HNCR upward trend $(0.53 \pm 0.01)$ is followed by a decrease in TVH. However, the HNCR is less indicative, since it depends on two components: the area of the nucleus and the area of the cytoplasm, which can change during both cell proliferation and hyperplasia, and atrophy phenomena [12]. As can be seen in Figure 2, with a progressive HBD decrease, by Day 35, the HNCR index demonstrated a weak growth, which can be explained by the atrophy of hepatocytes, i. e. the breakdown of compensatory-adaptive processes of the liver cells.

The TVH growth indicates a predominance of compensatory processes, and a decrease in this indicator to the value of a normal liver (on Day 21) and further (on Day 28 and Day 35) is critical, as it is accompanied by a peak mortality of the animals, which indicates liver decompensation in CEBDO.

Study limitations. This study is limited by investigation of animals that only were sacrificed - livers of the animals that died during the experiment were not studied.

Prospects for further research. These results should be compared with those obtained in other experimental models of cholestasis and in clinical conditions in patients with obstruction of the biliary tract.

\section{Conclusion}

In experimental CEBDO, reduction of the HBD index less than $60 \%$ and reduction of TVH less than the value of a normal liver are accompanied by highest mortality, i. e., are a sign of hepatic decompensation. That was preceded by the maximum proliferative activity of hepatocytes, the criterion of which is the HNCR index.

\section{Conflict of interest}

There is no conflict of interest.

\section{References}

1. Wu, W., Yang, Y., Huang, Q. (2001). Bilirubin metabolism after obstructive jaundice in rats. Zhonghua Gan Dan Wai Ke Za Zhi, 5, 288-291.

2. Marques, T. G., Chaib, E., Fonseca, J. H. da, Lourenço, A. C. R., Silva, F. D., Ribeiro Jr, M. A. F. et. al. (2012). Review of experimental models for inducing hepatic cirrhosis by bile duct ligation and carbon tetrachloride injection. Acta Cirurgica Brasileira, 27 (8), 589-594. doi: http://doi.org/10.1590/s0102-86502012000800013

3. Dondorf, F., Fahrner, R., Ardelt, M., Patsenker, E., Stickel, F., Dahmen, U. et. al. (2017). Induction of chronic cholestasis without liver cirrhosis - Creation of an animal model. World Journal of Gastroenterology, 23 (23), 4191-4199. doi: http://doi. org/10.3748/wjg.v23.i23.4191

4. Wright, J. E., Braitwaite, J. L. (1964). The effects of ligation of the common bile duct in the rat. Journal of Anatomy, 98 (2), $227-233$.

5. Matenaers, C., Popper, B., Rieger, A., Wanke, R., Blutke, A. (2018). Practicable methods for histological section thickness measurement in quantitative stereological analyses. PLOS ONE, 13 (2), e0192879. doi: http://doi.org/10.1371/journal. pone.0192879

6. Heinrich, S., Georgiev, P., Weber, A., Vergopoulos, A., Graf, R., Clavien, P.-A. (2011). Partial bile duct ligation in mice: A novel model of acute cholestasis. Surgery, 149 (3), 445-451. doi: http://doi.org/10.1016/j.surg.2010.07.046

7. Prigge, J. R., Coppo, L., Martin, S. S., Ogata, F., Miller, C. G., Bruschwein, M. D. et. al. (2017). Hepatocyte Hyperproliferation upon Liver-Specific Co-disruption of Thioredoxin-1, Thioredoxin Reductase-1, and Glutathione Reductase. Cell Reports, 19 (13), 2771-2781. doi: http://doi.org/10.1016/j.celrep.2017.06.019

8. Tietz, N. W. (Ed.) (1995). Clinical guide to laboratory tests. Philadelphia: WB saunders, 268-273.

9. Yang, Y., Chen, B., Chen, Y., Zu, B., Yi, B., Lu, K. (2014). A comparison of two common bile duct ligation methods to establish hepatopulmonary syndrome animal models. Laboratory Animals, 49 (1), 71-79. doi: http://doi.org/10.1177/ 0023677214558701

10. Ertor, B., Topaloglu, S., Calik, A., Cobanoglu, U., Ahmetoglu, A., Ak, H. et. al. (2013). The Effects of Bile Duct Obstruction on Liver Volume: An Experimental Study. ISRN Surgery, 2013, 1-7. doi: http://doi.org/10.1155/2013/156347 
11. Kordzaia, D., Jangavadze., M. (2014). Unknown bile ductuli accompanying hepatic vein tributaries (experimental study). Georgian Med News, 234, 121-129.

12. Mamontov, I. M., Ivakhno, I. V., Tamm, T. I., Panasenko, V. O., Padalko, V. I., Zulfugarov, I. (2019). Morphological signs of the hepatic function decompensation with experimental complete obstruction of the extrahepatic bile ducts. World of Medicine and Biology, 15 (67), 162-166. doi: http://doi.org/10.26724/2079-8334-2019-1-67-162

Received date 18.12.2019

Accepted date 17.01.2020

Published date 31.01.2020

Mamontov Ivan, PhD, Associate Professor, Department of Surgery and Proctology, Kharkiv Medical Academy of Postgraduate Education, Amosova str., 58, Kharkiv, Ukraine, 61176

E-mail: ivan.n.mamontov@gmail.com

Ivakhno Igor, PhD, Teaching Assistant, Doctor-Pathologist, Department of pathology, Kharkiv Medical Academy of Postgraduate Education, Amosova str., 58, Kharkiv, Ukraine, 61176;

Kharkiv City Clinical Hospital No. 17, Moskovsky ave., 195, Kharkiv, Ukraine, 61037

E-mail: igorv.ivakhno@gmail.com

Tamm Tamara, MD, Professor, Head of Department, Department of Surgery and Proctology, Kharkiv Medical Academy of Postgraduate Education, Amosova str., 58, Kharkiv, Ukraine, 61176

E-mail: tamm_ti@ukr.net

Panasenko V'yacheslav, Assistant, Department of Histology, Cytology and Embryology, Kharkiv National Medical University, Nauky ave., 4, Kharkiv, Ukraine, 61022

E-mail: v.o.pan@ukr.net

Padalko Volodymyr, PhD, Senior Researcher, Associate Professor, Department of General and Clinical Pathology, V. N. Karazin Kharkiv National University, Svobody sq., 4, Kharkiv, Ukraina, 61022

E-mail: padalko@karazin.ua

Zulfugarov Ismat, Postgraduate student, Department of surgery and proctology, Kharkiv Medical Academy of Postgraduate Education, Amosova str., 58, Kharkiv, Ukraine, 61176

E-mail: abramovmatvey26@gmail.com 